\title{
A uniform thymic malignant lymphoma model established with C57BL/6 p53 gene deficient mice
}

\author{
Changfa Fan ${ }^{1, *}$, Jianjun Lyu ${ }^{2, *}$, Susu Liu ${ }^{1, *}, \mathbf{X i}_{\mathbf{i}} \mathbf{W u}^{1}$, Qianqian $\mathrm{Li}^{2}$, Shuya Zhou ${ }^{1}$, \\ Yanwei Yang ${ }^{2}$, Guitao Huo ${ }^{2}$, Qin Zuo ${ }^{1}$, Qingfen Zhu ${ }^{3}$, Ming Guo ${ }^{3}$, Simei Ren ${ }^{4}$, Yanan \\ Guo $^{5}$, Sanlong Wang ${ }^{2}$, Baowen $\mathrm{Li}^{1}$, Xue Wang ${ }^{2}$, Yuelei Shen ${ }^{5}$ and Youchun Wang ${ }^{1}$ \\ ${ }^{1}$ Division of Animal Model Research, Institute for Laboratory Animal Resources, National Institutes for Food and Drug Control, \\ Tiantan Xili, Beijing 100050, China \\ ${ }^{2}$ National Center for Safety Evaluation of Drugs, Institute for Food and Drug Safety Evaluation, National Institutes for Food \\ and Drug Control, Beijing Economic-Technological Development Area, Beijing 100176, China \\ ${ }^{3}$ Shandong Institute for Food and Drug Control, High-Tech Zone, Jinan 250101, China \\ ${ }^{4}$ Department of Hematology, National Center for Clinical Laboratories and Beijing Hospital, Beijing 100730, China \\ ${ }^{5}$ Beijing Biocytogen Co. LTD, Economic-Technological Development Area, Beijing 101111, China \\ *These authors contributed equally to this work
}

Correspondence to: Youchun Wang, email: wangyc@nifdc.org.cn

Keywords: $p 53$ deficient mouse; lymphoma model; MNU induction; C57BL/6 genetic background; T cell lineage

Received: November 01, $2016 \quad$ Accepted: December 03, $2017 \quad$ Published: January 02, 2018

Copyright: Fan et al. This is an open-access article distributed under the terms of the Creative Commons Attribution License 3.0 (CC BY 3.0), which permits unrestricted use, distribution, and reproduction in any medium, provided the original author and source are credited.

\section{ABSTRACT}

Lymphoma is the third most common cancer diagnosed in children and $\mathrm{T}$ cell lymphoma has the worst prognosis by clinical observation. So far, a lymphoma model with uniform penetrance has not been available. In this paper, we generated a p53 deficient mouse model by targeting embryo stem cells derived from the C57BL/ 6 mouse strain. Homozygous p53 deficient mice exhibited more accelerated rate of spontaneous tumorigenesis with a high spontaneous occurrence rate $(93.3 \%)$ of malignant lymphoma. Because tumour models with a high phenotypic consistency are currently needed, we further generated the lymphoma model by single intraperitoneal injection of 37.5 or $75 \mathrm{mg} / \mathrm{kg} \mathrm{N}$-methyl-N-nitrosourea (MNU) to p53 deficient mice. Lymphoma and retinal degeneration occurred in $100 \%$ of $p 53^{+/-}$mice administrated higher concentration of MNU, which was much higher than previously reported models. The main anatomic sites of lymphoma were thymus, spleen, bone marrow, and lymph nodes. Both induced and spontaneous lymphomas in the thymus and spleen were stained positive for CD3 antigen. Furthermore, positive CD4 and/or positive CD8 cells were detected by flow cytometry, indicating a T-cell lineage of the lymphomas. The onset time of this uniform lymphoma model was from 13 to 17 weeks after the administration of MNU accompanied by the second time of weight loss. Based on our observations and previous data, we hypothesised that mice with the B6 background are prone to lymphomagenesis. This model could be used to study the mechanisms of lymphomagenesis, to select new drugs, and to improve the reproducibility of experimental results.

\section{INTRODUCTION}

Hodgkin lymphoma and non-Hodgkin lymphoma are the third most common cancer diagnosed in children worldwide [1]. Although the prognosis of patients has been significantly improved because of the progress of the study of the pathogenesis and new therapies, the overall outcomes of treatment remain poor. An appropriate animal model mimicking human disease conditions is crucial for facilitating our understanding of the basic mechanism of lymphoma pathogenesis as well as developing effective new anti-tumour drugs and treatment options. Various 
lymphoma animal models have been reported, among which mouse models are the most popular. In the early 1970s [2], a transplantable tumour was injected into CBA mice to model Gardner lymphosarcoma. The generation of adult T-cell leukaemia/lymphoma [3] and human acute B-lymphoblastic leukaemia [4] by xenotransplantation of primary peripheral blood mononuclear cells into combined immunodeficient mice were reported recently. In addition to the use of immunodeficient mice, irradiation or thymectomy have also been used to optimize models [5]. Genetically modified mice have also been studied intensively as potential lymphoma models [6-10]

$p 53$ is a well-known tumour suppressor gene, $p 53$ knocked out mice appear spontaneous carcinogenesis [11]. A variety of tumours have been reported in $p 53$ mutant mice of different genetic backgrounds. Lymphoma was observed in $47 \%$ and $53 \%$ of homogenous $p 53$ deficient mice of the $129 / \mathrm{Sv}$ and BALB/c backgrounds, respectively $[6,7]$. p53 deficient mice of mixed C57BL/6 and 129/Sv backgrounds (75\% C57BL/6 and 25\% 129/Sv) exhibited $65 \%-75 \%$ incidence of lymphoma $[6,12]$. Because a high percentage of tumours from $p 53$ mutant mice are lymphomas, $p 53$ mutant mice are regarded as a potential model for lymphoma pathogenesis study. However, its low penetrance ratio has hampered further mechanistic studies. Carcinogen-induced models have also been investigated to improve the incidence of lymphoma. When B6.129Trp53 N5 heterozygous mice were subjected to N-methyl$\mathrm{N}$-nitrosourea (MNU) induction, $85 \%$ of mice developed lymphoma within six months [8].

In the present study, a uniform lymphoma model was established by deletion of the $p 53$ gene of the C57BL/6 background mice. Homozygous $p 53$ mutant mice were viable and $93.3 \%$ developed spontaneous lymphomas from 12 to 37 weeks. Furthermore, 100\% heterozygous mice induced with $75 \mathrm{mg} / \mathrm{kg}$ of MNU developed lymphomas, and induced tumour incidence showed a doseeffect relationship with MNU. Lymphoblasts in thymic lymphomas stained positive for mouse $\mathrm{CD} 3$ antigen, and represented CD4 positive and/or, CD8 positive detected by flow cytometry, indicating a T-cell lineage.

\section{RESULTS}

\section{Generation of C57BL/6 mouse ES cells}

Although most ES targeting has been performed using ES cells on the 129/Sv background, an ES cell line isolated from the C57BL/6 inbred strain has the advantage of a much cleaner background and no need for reciprocal backcrossing. In this study, we used an ES cell line (Figure 1A) established from C57BL/6 mice to generate knockout mice. We examined the karyotype of ES cells and confirmed that they were male (XY) and the chromosome number was normal (Figure 1B). This ES cell line was reported to have high germline transmission efficiency. By using this highly efficient and hereditary stable C57BL/6 ES cell line, we generated $p 53$ gene knockout mice by ES targeting.

\section{Generation of $p 53 \Delta^{2-5 /+}$ mice}

A targeting vector containing a phosphoglycerate kinase (PGK) promoter driving a Neo cassette was generated. The Neo cassette replaced exon 2 to exon 5 of the $p 53$ gene, which accounted for approximately $40 \%$ of the coding region (Figure 1C). The $p 53$ targeting vector was electroporated into the established C57BL/6 ES cell line and ES cells were screened by G418. G418 resistant colonies were further confirmed by Southern blotting. The 5'probe hybridized to an EcoRI fragment of approximately $17 \mathrm{~kb}$ from the wild-type $p 53$ allele, whereas induction of the PGK-Neo cassette in a mutant allele contained another $E c o$ RI site that yielded a 7-kb fragment (Figure 1D). Four heterozygous ES cell clones were subjected to blastocyst injection. A total of 151 wild-type BALB/c blastocysts were injected and 24 chimera mice were produced. The male chimera mice were crossed with C57BL/6 female mice and $37 \mathrm{~F} 1$ mice with black fur and 48 mice with white fur were obtained (Table 1). Some F1 male and female heterozygous mice were further intercrossed to generate homozygous $p 53$ gene knockout mice (Figure 1E).

The deletion of exon 2 to exon 5 theoretically abolished $p 53$ transcription. To prove that the $p 53^{\Delta 2-5 /+}$ allele was a null allele, the expression of $p 53$ gene was checked. We analysed total RNA derived from liver, spleen, lung, brain, and thymus. Heterozygous mice approximately exhibited half of the normal p53 gene expression level observed in wild-type mice, whereas homozygous mice did not express p53 mRNA at all. These results were confirmed by two independent pairs of primer, one pair primer located in exon 4 and 5 , and the other located in exon 9 and 10 (Figure 1F). This model is named as B6-Trp $53^{\text {tmIDAMR }} / \mathrm{NIFDC}$, and is referred to as $p 53^{-/}$in this study.

\section{High frequency of spontaneous lymphoma in p53 ${ }^{-/}$mice}

According to Knudson's two-hit hypothesis [13], $p 53^{--}$mice of various genetic backgrounds develop spontaneous tumours much earlier than $p 53^{+/}$mice $[6,7$, $12,14]$. As shown in Figure 2A, $p 53^{-/-}$mice did exhibit more accelerated rate of tumorigenesis than that of heterozygous or wild-type mice. About $50 \%$ of $p 53^{-/-}$mice were moribund and euthanized for anatomic study before 26 weeks, and all died before 32 weeks. However, all the wild-type and $90 \%$ of $p 53^{+/-}$mice survived until the end of the study.

Necropsy showed obvious thymus enlargement in 23 of 30 mice. Microscopic observation found out 
Table 1: Generation of C57BL/6-p53 ${ }^{+/-}$deficient mice by blastocyst microinjection

\begin{tabular}{cccccccc}
\hline $\begin{array}{c}\text { ES cell } \\
\text { subclones }\end{array}$ & $\begin{array}{c}\text { Blastocysts } \\
\text { injected }\end{array}$ & $\begin{array}{c}\text { Blastocysts } \\
\text { transferred }\end{array}$ & Newborns & \multicolumn{2}{c}{ Chimers } & \multicolumn{2}{c}{ F1 mice } \\
\cline { 5 - 8 } H7 & 67 & 67 & 10 & 2 & 9 & 9 & 0 \\
A1 & 33 & 33 & 4 & 1 & 2 & 7 & 10 \\
E10 & 34 & 34 & 15 & 4 & 7 & 15 & 8 \\
E12 & 17 & 17 & 5 & 1 & 3 & 8 & 5 \\
\hline
\end{tabular}

that the most frequently observed tumour of the $p 53^{-1-}$ homozygotes was malignant lymphoma, affecting 28 of 30 tumour-bearing mice. Of the remaining 2 mice, one had rhabdosarcoma and the other had adenocarcinoma (Table 2). The tumour frequencies of malignant lymphoma, rhabdosarcoma, leiomyosarcoma, and adenocarcinoma were $93.3 \%, 13.3 \%, 10 \%$ and $3.3 \%$, respectively (Figure 2B). These data implied that this model was susceptible to tumour development.

22 of 30 mice $(73.3 \%)$ only developed lymphoma, 3 mice had both lymphoma and rhabdosarcoma, and 3 animals had both lymphoma and leiomyosarcoma. The relative frequency of lymphoma occurrence was $92.5 \%$; the second most common tumour was rhabdosarcoma, accounting for $3.7 \%$ of all tumours (Figure 2C). The tumour spectrum was quite different from that observed for p53 gene knockout mice of different genetic backgrounds. Donehower reported that 10 kinds of tumours were observed $[6,11]$, while only four types of tumours were found in this homozygote of the $\mathrm{B} 6$ background, indicating $p 53^{--}$mice on a C57BL/6 background predominantly developed lymphoma.

The anatomic sites of tumours included the spleen, thymus, liver, kidney, heart, lung, and stomach. As expected, malignant lymphoma occurred mainly in the spleen and thymus, with a rate of $70 \%$, indicating the spleen and thymus were the primary organs of lymphoma in this model. Moreover, lymphoma was also observed
A

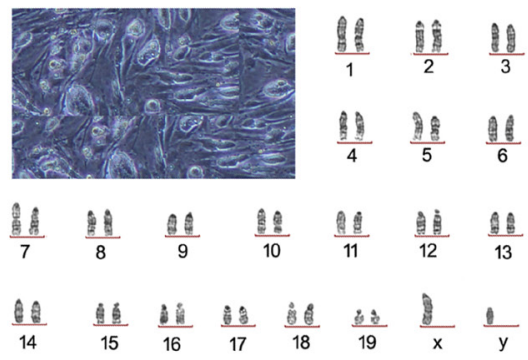

D

$\mathrm{E}$

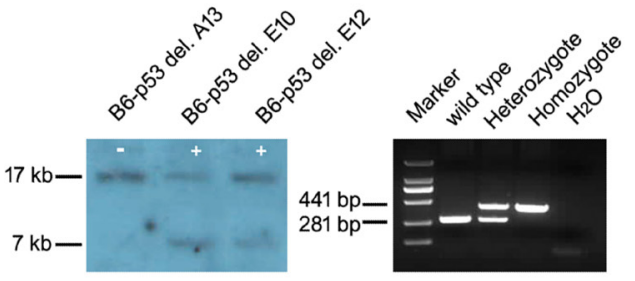

C

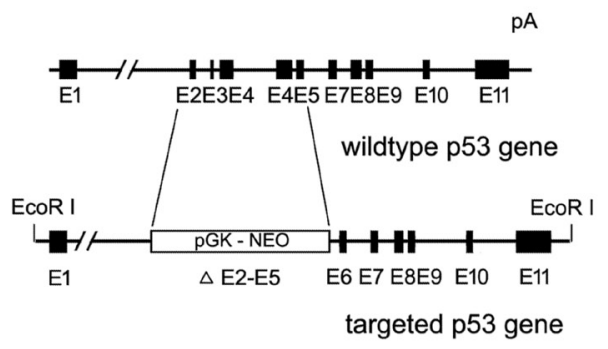

$\mathrm{F}$

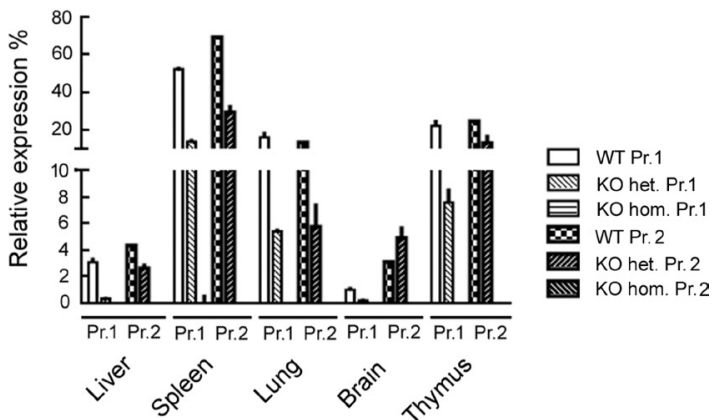

Figure 1: Establishment and verification of a p53 gene knockout mouse model. (A) Image of $p 53$ gene targeted ES cells on a C57BL/6 background. (B) Karyotype of targeted ES cells. (C) Schematic representation of $p 53$ gene knockout construction; exons 2-5 were replaced by a Neo cassette. (D) Southern blotting analyses of mouse tail DNA. Genomic DNA was extracted from ES cells and used for Southern blot analysis. After digestion with EcoRI (for the 5' probe), the probe hybridized to a $17 \mathrm{~kb}$ fragment from the wild-type allele $(+)$ and a $7 \mathrm{~kb}$ fragment from the $p 53$ gene knockout allele (-). (E) PCR genotyping analysis of wild type, heterozygous, and homozygous p53 gene knockout mice. The expected sizes of PCR products are $281 \mathrm{bp}$ for the wild-type allele and $561 \mathrm{bp}$ for the knockout allele. (F) Relative real-time PCR analysis of the $p 53$ gene mRNA by two primers sets in the liver, spleen, lung, brain, and thymus of wild-type, heterozygous, and homozygous $p 53$ gene knockout mice. Forward primer 1 located in exon 4 of $p 53$ gene, reverse primer 1 located in exon5, forward and reverse primer 2 located in exon 9 and exon10, respectively. Values are shown as the mean \pm SD for three independent experiments and were normalized to the corresponding Gapdh levels. 
Table 2: Spontaneous tumors in $p 53$-deficient homozygous $\left(p 53^{-/}\right)$mice

\begin{tabular}{|c|c|c|c|c|}
\hline Case & Sex & Age(weeks) & Histologic types & Anatomic sites \\
\hline \multirow[t]{2}{*}{1} & \multirow{2}{*}{$\hat{0}$} & \multirow{2}{*}{20} & Malignant lymphoma & Spleen; \\
\hline & & & Rhabdosarcoma & Muscle; \\
\hline 2 & $\hat{o}$ & 25 & Malignant lymphoma & $\begin{array}{c}\text { Thymus, spleen, liver, heart, kidney, lung, } \\
\text { submandibular gland, stomach; }\end{array}$ \\
\hline 3 & $\hat{\sigma}$ & 23 & Malignant lymphoma & Thymus, heart; \\
\hline 4 & $\hat{0}$ & 24 & Malignant lymphoma & Spleen; \\
\hline \multirow[t]{2}{*}{5} & \multirow{2}{*}{$\hat{\sigma}$} & \multirow{2}{*}{22} & Malignant lymphoma & Spleen; \\
\hline & & & Leiomyosarcoma & Stomach; \\
\hline 6 & $\hat{o}$ & 28 & Malignant lymphoma & Spleen; \\
\hline 7 & $\hat{0}$ & 12 & Malignant lymphoma & Thymus, heart; \\
\hline 8 & $\hat{0}$ & 28 & Malignant lymphoma & Thymus, spleen, liver, heart, kidney; \\
\hline \multirow[t]{2}{*}{9} & \multirow{2}{*}{$\hat{0}$} & \multirow{2}{*}{16} & Malignant lymphoma & Thymus, liver, kidney; \\
\hline & & & Rhabdosarcoma & Muscle; \\
\hline 10 & q & 31 & Malignant lymphoma & Thymus, spleen, liver, lung; \\
\hline 11 & $\hat{0}$ & 23 & Malignant lymphoma & Thymus, spleen, liver, kidney, heart; \\
\hline 12 & $\hat{0}$ & 23 & Malignant lymphoma & Spleen, liver; \\
\hline 13 & $\hat{0}$ & 28 & Malignant lymphoma & Thymus, spleen, liver, kidney, lung; \\
\hline \multirow[t]{2}{*}{14} & \multirow{2}{*}{$\sigma^{\lambda}$} & \multirow{2}{*}{28} & Malignant lymphoma & Spleen, liver; \\
\hline & & & Rhabdosarcoma & Muscle; \\
\hline 15 & 우 & 16 & Malignant lymphoma & Thymus, spleen, liver; \\
\hline 16 & $\hat{0}$ & 12 & Adenocarcinoma & Jejunum; \\
\hline 17 & $\hat{o}$ & 20 & Malignant lymphoma & $\begin{array}{c}\text { Thymus, spleen, liver, kidney, lung, heart, } \\
\text { bone marrow; }\end{array}$ \\
\hline 18 & $\hat{0}$ & 22 & Rhabdosarcoma & Muscle; \\
\hline 19 & $\hat{0}$ & 26 & Malignant lymphoma & Thymus, bone marrow; \\
\hline 20 & $\hat{0}$ & 26 & Malignant lymphoma & Thymus, heart, liver; \\
\hline 21 & $\hat{o}$ & 32 & Malignant lymphoma & $\begin{array}{l}\text { Thymus, spleen, liver, kidney, lung, heart, } \\
\text { bone marrow, submandibular gland, adrenal, } \\
\text { eye, urinary bladder, stomach, epididymis, } \\
\text { mesenteric lymph node; }\end{array}$ \\
\hline 22 & $\hat{0}$ & 24 & Malignant lymphoma & Thymus, kidney, pancreas; \\
\hline 23 & $\hat{0}$ & 24 & Malignant lymphoma & Thymus, spleen, kidney, liver, brain; \\
\hline 24 & $\hat{0}$ & 24 & Malignant lymphoma & Thymus, spleen; \\
\hline 25 & $\hat{0}$ & 24 & Malignant lymphoma & Thymus, spleen; \\
\hline 26 & 0 & 24 & Malignant lymphoma & Thymus, liver; \\
\hline 27 & $\sigma^{\pi}$ & 24 & $\begin{array}{l}\text { Malignant lymphoma } \\
\text { Leiomyosarcoma }\end{array}$ & $\begin{array}{l}\text { Thymus, spleen, liver; } \\
\text { Stomach; }\end{array}$ \\
\hline 28 & $\hat{0}$ & 24 & Malignant lymphoma & Thymus, spleen, liver; \\
\hline 29 & $0^{\pi}$ & 24 & $\begin{array}{l}\text { Malignant lymphoma } \\
\text { Leiomyosarcoma }\end{array}$ & $\begin{array}{l}\text { Thymus, spleen, kidney, liver; } \\
\text { Jejunum; }\end{array}$ \\
\hline 30 & $\hat{0}$ & 24 & Malignant lymphoma & Spleen, liver, kidney, inguinal lymph node; \\
\hline
\end{tabular}


frequently in the bone marrow, lymph nodes, liver, kidney, and heart, etc. (Figure 2D). Rhabdosarcoma was observed in muscle, adenocarcinoma was found in the jejunum, and two mice had leiomyosarcoma in the stomach.

\section{Generation of a lymphoma model by MNU induction in $p 53^{+/-}$mice}

Since this $p 53^{-/-}$mice with C57BL/6 background had higher occurrence of lymphoma (93.3\%) than that of other strains $[6,12]$, we want to generate a lymphoma model with higher consistency and earlier occurrence. Genotoxic carcinogens are generally referred to as initiating agents of tumorigenesis because they damage DNA and induce mutations in key target genes, which is thought to be the initial event leading to cancer development [15]. MNU is a widely used positive genotoxic carcinogen for $p 53$ deficient mice and other transgenic mice in carcinogenicity studies $[8,16]$. Therefore, we used MNU to shorten the lymphoma occurrence time and to establish an efficient tumour model.

Wild-type, $p 53^{+/-}$, and $p 53^{-/-}$mice were administered $37.5 \mathrm{mg} / \mathrm{kg}$ of MNU dissolved in citrate buffered saline adjusted to $\mathrm{pH} 4.5$ by single intraperitoneal injection. All the $p 53^{-/}$mice died within one week post administration, while $p 53^{+/-}$and wild-type mice survived until the end of the experiments (Figure 3A). Since tumors usually do not develop within a week, only wild-type and $p 53^{+/-}$ mice were further observed. The frequency of lymphoma occurrence was $65 \%$ in $p 53^{+/}$mice and $10 \%$ in wildtype mice (Figure 3B, $P<0.05$ ). Except for malignant lymphoma, no other types of tumours were observed (Figure 3C). The lymphoma frequency in different organs was shown in Figure 3D, and higher incidences of tumour were observed in the thymus and spleen.

To further test tumour incidence and uniformity of the model, a group of $p 53^{+/-}$mice were administered $75 \mathrm{mg} / \mathrm{kg} \mathrm{MNU}$ by single intraperitoneal injection. The onset of tumorigenesis of $p 53^{+/}$mice administrated 75 $\mathrm{mg} / \mathrm{kg} \mathrm{MNU}$ group was much earlier that of $p 53^{+/-}$mice administrated $37.5 \mathrm{mg} / \mathrm{kg}$ MNU. Because most animals died between 13 and 17 weeks, other survived animals were sacrificed by 23 weeks (Figure 4A). This result indicated that the increased MNU concentration could accelerate the development of tumour.

Microscopic findings showed that malignant lymphoma was the most predominant tumour, occurring in $100 \%$ of mice at the end of experiment. The second most common tumour was adenoma, with a rate of $43 \%$ (Figure 4B). Unlike other spontaneous tumour models, rhabdosarcoma and leiomyosarcoma were not observed. Figure 4C shows the tumour distribution in this animal group; as expected, the most common tumour was lymphoma (87\%), and the proportion of adenoma was $13 \%$.

We further investigated the incidence of lymphoma in different organs. Tumours were mainly present in the lymphoid organs, including the thymus (100\%), spleen $(100 \%)$, bone marrow $(93 \%)$, mesenteric lymph nodes (57\%), inguinal lymph nodes $(57 \%)$, and mandibular lymph nodes (29\%). Lymphoma was also found in some non-lymphoid organs, such as the kidney, lung, and liver (Figure 4D). In contrast to the $37.5 \mathrm{mg} / \mathrm{kg} \mathrm{MNU}$ group (Figure 3D), the lymphatic system showed a high number of lesions, and the tumour incidence increased from $65 \%$ to $100 \%$. With the advantage of easy sampling and high rate of lymphomagenesis, the thymus and spleen can be used as the most appropriate target organs for the study of mechanisms of lymphomagenesis.

Organ enlargement was observed frequently by gross pathological examination (Table 3 ), and the occurrence rate of thymus mass and enlarged spleen was higher than that of other organs. To investigate organ enlargement further, the weight of the heart, spleen, lung, kidney, brain, thymus, salivary gland, adrenal gland, ovaries, and uterus were measured. Figure 5 shows that the absolute weight and relative organ weight of the spleen and thymus were heavier in the $75 \mathrm{mg} / \mathrm{kg} \mathrm{MNU}$ group than that of the control group $(P<0.05)$.

\section{T-cell lineage of the malignant lymphomas of thymus and spleen}

To determine the cell origin of the malignant lymphoma, we performed immunohistochemistry staining of sections from 5 male and 5 female MNU-treated $p 53^{+/-}$ mice. (Figure 6A-6G) and $4 p 53^{-/-}$mice diagnosed with spontaneous thymus and spleen malignant lymphoma using antibodies directed against CD3 (T lymphocyte marker), CD20 (B lymphocyte marker), and CD68 (macrophage marker). All neoplastic cells in thymus and spleen malignant lymphoma sections from animals with induced or spontaneous malignant lymphoma were positive for $\mathrm{CD} 3$ (Figure $6 \mathrm{H}, 6 \mathrm{~K}$ ) and negative for CD20 (Figure 6I, 6L) and CD68 (Figure 6J, 6M), indicating that the malignant lymphomas were of T-cell lineage, consistent with previous reports $[8,14]$. To further confirm the cell origin, the whole thymic and splenic cells were isolated for flow cytometry assay. The lymphoma cells were TCR $\beta+$, TCR g $\delta$-, NKp46- cells (data not shown). Further analysis indicated that CD4+ and CD8+ cells were observed in thymus and spleen from animals with lymphomas or wild type mice, but CD4 and CD8 double positive cells mainly found in thymus (Supplementary Figure 1A, 1B), only differentiated CD4+ or CD8+ population were found in spleen (Supplementary Figure $1 \mathrm{C}$ and 1D). The ratio of $\mathrm{CD} 4+, \mathrm{CD} 8+$, double positive, and double negative cell populations were different in $p 53^{-/-}$mice with thymic lymphoma, to represent $29.2 \%$, $15 \%, 31 \%$, and $24 \%$ of total lymphocyte as compared with $12.3 \%, 6 \%, 74 \%$ and $5.3 \%$ in wild type mice, respectively (Supplementary Figure 1E), indicating lymphomagenesis might occur after the formation of CD4 and CD8 double 


\begin{tabular}{lccccc}
\hline \multicolumn{1}{c}{ Dose } & MNU 75 $\mathbf{~ m g / k g}$ & MNU 37.5 $\mathbf{~ m g / k g}$ & \multicolumn{2}{c}{ Citrate buffer } \\
\hline Numbers of animals & $P 53^{+/}$ & WT & $P 53^{+/-}$ & WT & $P 53^{+/-}$ \\
Numbers of animals tumourgenesis* & 14 & 20 & 17 & 10 & 19 \\
Thymus, enlarged & 14 & 2 & 11 & 0 & 0 \\
Thymus, mass & 6 & 0 & 5 & 0 & 0 \\
Spleen, enlarged & 1 & 0 & 0 & 0 & 0 \\
Spleen, mass & 10 & 1 & 8 & 0 & 0 \\
Inguinal lymph node, enlarged & 2 & 0 & 2 & 0 & 0 \\
Mesenteric lymph node, enlarged & 0 & 0 & 3 & 0 & 0 \\
Mandibular lymph node, enlarged & 0 & 0 & 2 & 0 & 0 \\
Kidney, mass & 0 & 0 & 0 & 0 & 0 \\
Liver, enlarged & 0 & 0 & 2 & 0 & 0 \\
Liver, mass & 2 & 0 & 3 & 0 & 0 \\
Lung, mass & 0 & 0 & 3 & 0 & 0 \\
\hline
\end{tabular}

Note: " the animal number of tumourigenesis is confirmed by microscopic findings.

positive T lymphocyte [17]. The present observation was different to that of Donehower et al. [6], that is, both B and $\mathrm{T}$ lymphomas were found. The reason might be due to the different backgrounds of mice used in the studies.

\section{Body weight, and haematological and biochemistry analyses}

To examine the characteristics of the lymphoma model, we monitored the clinical features and body weight change from the time of MNU administration to death or sacrifice. We also measured haematological and blood biochemical parameters at the end of six months. Clinical symptoms, such as decreased activity, hunched back, listlessness, thinness, and rapid breathing patterns were observed at about 12-13 weeks after the administration of MNU. All animals administered citrate buffer (controls) did not show any clinical signs and survived until sacrifice. Mice administered $75 \mathrm{mg} / \mathrm{kg}$ MNU exhibited significantly decreased body weights compared with those administered citrate buffer at 2-3 weeks after dosing. This body weight loss may be caused by the acute toxicity of this chemical [5]. Although the body weight of mice administered MNU gradually recovered, it remained lower than that of citrate buffer control animals at most time points. A second body weight decrease occurred at 12-13 weeks post dosing (Figure 7), probably due to the progression of malignant lymphoma, which is in accord with the time of moribund/ death of many animals (Figure 4A) and the appearance of clinical symptoms.

In the haematological analysis, we counted the total number of white blood cell, neutrophilic granulocyte, lymphocyte, monocyte, eosinophil, basophil and red blood cell, and calculated their relative percentages. We found the cell number of neutrophilic granulocyte were higher in the $p 53^{+/-} \mathrm{MNU}$ group than in the citrate buffer controls $(P<0.05)$, while the lymphocyte number and its relative percentage did not increase significantly $(P>$ $0.05)$. The neutrophilic granulocyte increase might have resulted from systemic inflammatory responses occurring at the end stage of the tumour, because cellular infiltration was observed in various organs by histopathology. The red blood cell number, haemoglobin, and total protein was decreased significantly $(P<0.05)$ in the $p 53^{+/-}$MNU group. Four biochemistry parameters, triglyceride, urea, total cholesterol, and calcium, were increased and serum albumin and creatinine were decreased in the MNU group, compared with the citrate buffer group at the end of the experiment (Supplementary Figure 2).

\section{Non-neoplastic microscopic findings in the $p 53^{+/-}$ mouse lymphoma model}

Non-neoplastic microscopic findings included adenomatous hyperplasia of the duodenum and jejunum, glandular hyperplasia of the duodenum, and retinal degeneration of eyes (Supplementary Figure 3). The characteristics of adenomatous hyperplasia and glandular hyperplasia included an increase of crypt length and the number of cells per crypt, lengthened villi, and increased diameter of crypts but without formation of the circumscribed area of the epithelium. Notably, $100 \%$ of mice administered MNU had retinal degeneration, indicating this animal model had high homogeneity. 


\section{DISCUSSION}

Small, economical animal models have been widely used for the study of oncology mechanisms and the screening of therapeutic regimens [18]. An animal model with high phenotypic consistency may improve the reproducibility of experiments, reduce the number of animals required, and facilitate research on tumour pathogenesis. Here, we present a new lymphoma mouse model established by $p 53$ gene deletion in mice of the C57BL/6 background followed by MNU administration. We found out that $100 \% p 53^{+/ /}$knockout mice administrated high dose of MNU developed lymphomas. Animal death was observed mainly from 13 to 17 weeks post MNU administration (Figure 4), indicating this lymphoma model has the feature of uniform tumorigenesis, predictable early onset time, and high reproducibility.
The uniform tumorigenesis of this model may result from its homogeneous genetic background. Before the establishment of the B6 ES cell line in 2007 [19] and application of the CRISPR/Cas9 system in mammalian cells [20], most genetically modified animal models were developed by targeting ES cell lines derived from 129/Sv mice, which require several generations of backcrossing with $\mathrm{C} 57 \mathrm{BL} / 6$ to modify the genetic background. However, these mouse models still have a mixed background even after 20 generations of backcrossing. In the present study, the $p 53$ deletion model using a C57BL/6 derived ES cell line has a pure genetic background. Therefore, mice with the same genetic background developed uniform malignant lymphoma as well as retinal degeneration (Supplementary Figure 3).

According to the somatic mutation theory, genetics and the environment (carcinogens), as well as their interactions, can drive tumorigenesis [21-23]. p53 is a

\section{$\mathrm{P} 53^{-/-}$spontaneous tumour}

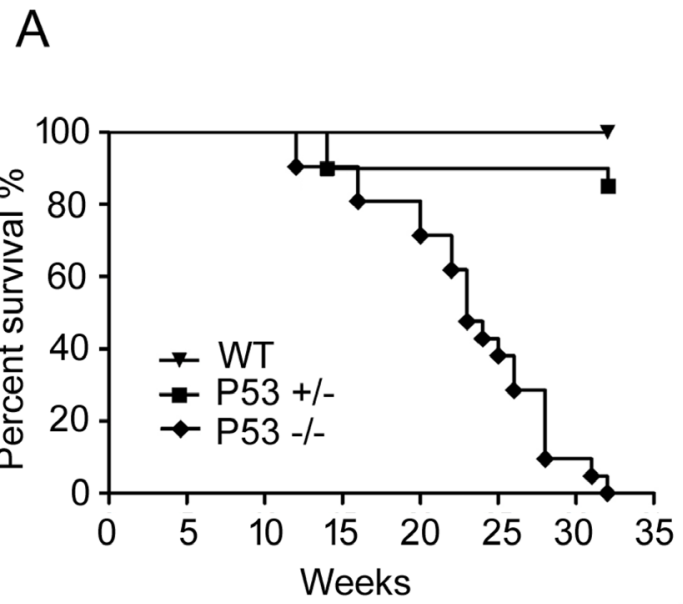

B
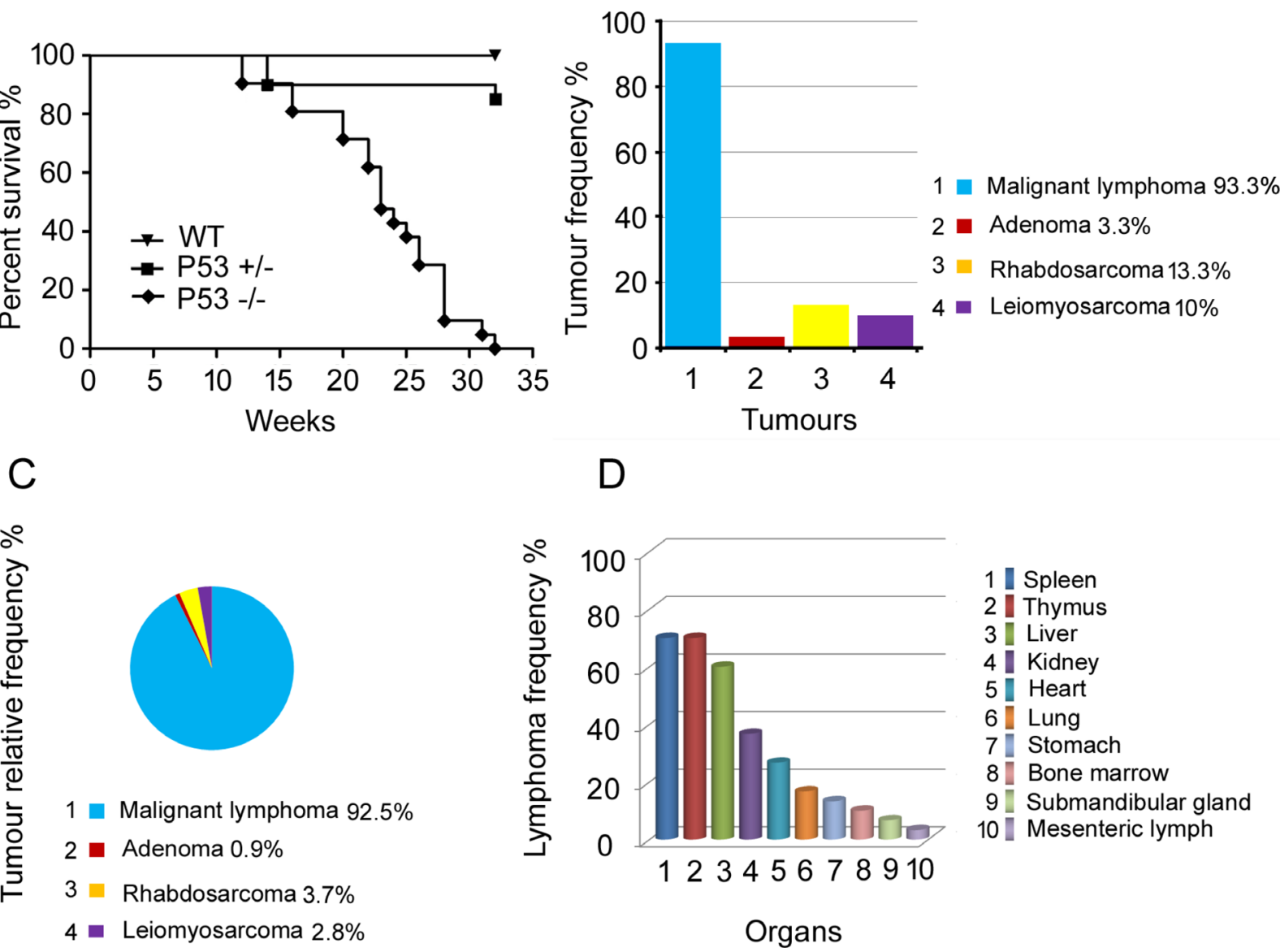

Figure 2: Spontaneous lymphoma occurrence in $\mathbf{p 5 3 ^ { - / - }}$ homozygous mice. (A) Survival curve of wild-type, $p 53^{-/-}$and $p 53^{+/-}$ mice. All homozygous mice died before 32 weeks, while heterozygote and wild-type mice survived until 32 weeks. (B) Spontaneous tumour profile and frequency of $p 53^{--}$. Malignant lymphoma was the most prominent type with an occurrence rate of $93.3 \%$. (C) Relative frequency of malignant lymphoma, adenoma, rhabdosarcoma, and leiomyosarcoma. (D) The top ten organs with a high incidence of lymphoma. 30 of $p 53^{-/ /}$homozygous mice were used in this experiment. 
crucial tumour suppressor gene and plays important role in physiological processes [24, 25]. Furthermore, p53 gene mutation or deletion promotes tumorigenesis in humans and animal models [18, 22, 26, 27]. The potential for carcinogens to induce or accelerate tumour genesis has also been reported intensively [8, 28, 29]. Different strategies have been used to develop lymphoma models, such as humanized mice, xenografting, [3, 4] or others $[30,31]$ to mimic the effect of genetic and environmental factors on tumorigenesis. Here, we established a lymphoma model with 4 months of latent period of lymphoma instead of over 6 months.

Parameters that affect tumorigenesis in p53deficient mice have been widely described, such as genetic background, status of the p53 gene (homozygous or heterozygous) $[6,12,14]$. According to a previous report, p53 gene deletion models on a B6 background were susceptible to lymphoma. Various mouse strains, including D3 [14], BALB/c [7], 129/Sv [6, 12], and C57BL/6 (this work) have been used for $p 53$ gene deletion models, all of which exhibited diverse tumour spectra and prominent tumour types. Table 4 shows that the top three spontaneous tumours in D3- $p 53^{+/-}$mice were osteosarcoma, lymphoma, and fibrosarcoma [14]. The main tumour types in BALB/c background $\mathrm{P5}^{+/-}$mice were mammary carcinoma, lymphoma, and hemangiosarcoma. Because the early onset of mammary carcinoma is the most common cancer in women with Li-Fraumeni syndrome, this model was considered a Li-Fraumeni syndrome model [7]. In 129/ $\mathrm{Sv}$ mice, the major tumours were osteosarcomas and lymphomas. However, only low lymphoma frequencies (from $22 \%$ to $25 \%$ ) were observed in these three mouse models. As expected, given Knudson's two-hit hypothesis [13], the profile of p53 gene deletion homozygous mice was quite different from heterozygotes; spontaneous lymphoma was the prominent tumour type, with frequencies up to $65 \%$ in BALB/c mice [7] and $71 \%$ in D3 [14] mice. Interestingly, we observed the frequency of spontaneous lymphoma was $47 \%$ in $129 / \mathrm{Sv}-p 53^{-/-}$ mice, $75 \%$ in C57BL/6 mice, and $25 \%$ in $129 / \mathrm{Sv}$ mixedbackground mice increasing to $65 \%-75 \%$ (Table 4 ), while in mice with $100 \%$ C57BL/6 background, the frequency of lymphoma was $93.3 \%$ (Figure 2). By linear regression, we demonstrated that frequency of lymphoma was positively correlated with the percentage of C57BL/6 background $\left(\mathrm{R}^{2}=0.85\right.$, Figure 8). However, when C57BL/6-p53

\section{Tumours induced by $37.5 \mathrm{mg} / \mathrm{kg}$ MNU}

A

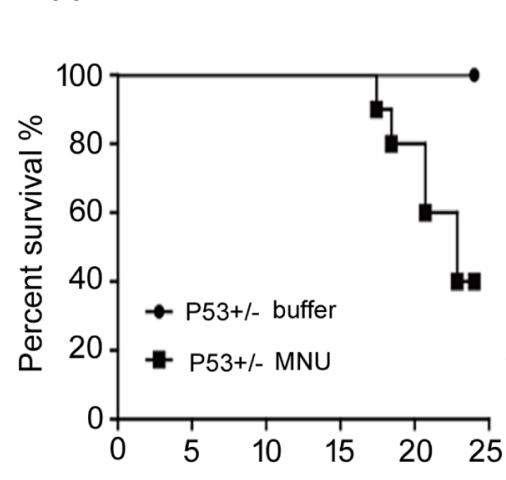

C

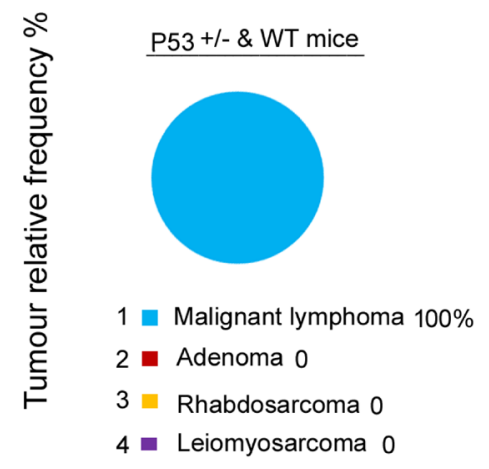

B
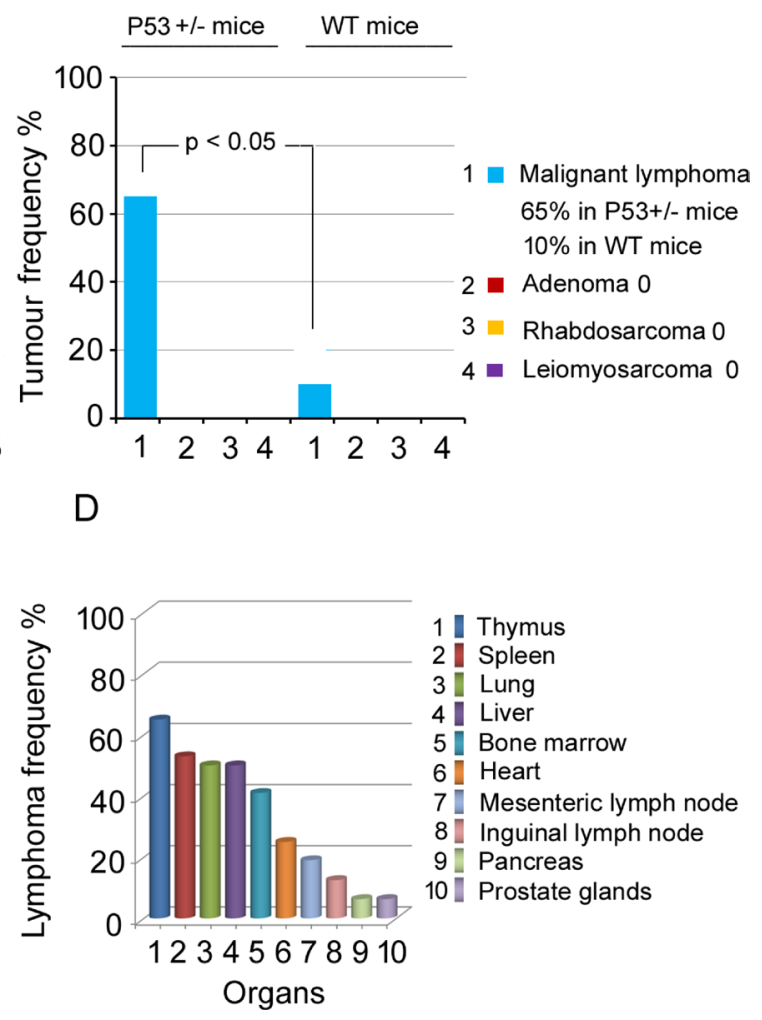

Figure 3: Lymphoma occurrence in $\mathbf{p 5 3}$ deficient heterozygous mice induced by $37.5 \mathrm{mg} / \mathrm{kg}$ MNU. (A) Survival curve of $p 53^{+/}$mice administered $37.5 \mathrm{mg} / \mathrm{kg}$ MNU. (B) The tumour profile and frequency of $p 53^{+/-}$and wild-type mice administered MNU. Only lymphomas were observed in both mouse strains. $p 53^{+/-}$mice were more susceptible to MNU than wild type mice. (C) The relative tumour frequency of lymphoma, adenoma, rhabdosarcoma, and leiomyosarcoma. (D) The malignant lymphoma frequency in various organs. 17 $p 53^{+/-}$and 20 wild type mice were used in this experiment. 
heterogeneous mice were induced with $75 \mathrm{mg} / \mathrm{kg}$ of $\mathrm{MNU}$, the frequency of lymphoma increased to $100 \%$ (Figure 4) in contrast with $85 \%$ in $129 / \mathrm{Sv}$ mice and B6 mixed-background mice [8]. Previous studies represented that the genetic background of mice may alter tumor development, but tumorigenesis is not strain-specific [12, 32]. Combined with our data and clinical observations [33], we hypothesise that tumour genesis is strain specific, and B6 background mice are lymphomagenesis prone, but how the B6 genetic background affects the tumour profile or frequency is still unknown.

Lymphomas in this model were of the $\mathrm{T}$ cell lineage because they were CD3, CD4, CD8 positive, and CD20 and CD68 negative (Figure 6, Supplementary Figure1). The present model is similar to the clinical T-cell lymphoma type with the worst prognosis in human patient [34]. Therefore, this model might be a useful tool for studying the mechanisms of lymphomagenesis and drug selection for treatment.

\section{MATERIALS AND METHODS}

Derivation of $\mathrm{C} 57 \mathrm{BL} / 6$ ES cells C57BL/6 mice were maintained in the 12-hour light/12- hour dark cycle. To obtain blastocysts, female mice were induced to superovulate and blastocysts were flushed out from uterine horns of $3.5 \mathrm{dpc}$ pregnant females. Blastocysts were cultured for 5-6 days on feeder cells in 12-well plates, and the ES cell medium was changed every 1-2 days. The size of ICMs increased markedly in culture. They consisted of a central mass of stem cells and peripheral primitive endoderm-like cells. They were picked up with a mouth-controlled micropipette into a 48 -well plate and then digested by $0.1 \%$ collagenase for $10-15 \mathrm{~min}$ followed by $0.25 \%$ trypsin for $2-5 \mathrm{~min}$. The digested ICMs were transferred onto new feeder cells for continuous cultures until ES cell colonies were observed.

\section{Mouse ES cell culture}

C57BL/6 ES cells were cultured at $37^{\circ} \mathrm{C}$ in a humidified $5 \% \mathrm{CO}_{2}$ incubator. They were routinely maintained on mitotically inactivated MEFs with Knockout DMEM medium (Gibco) supplemented with 15\% FBS (ExCell), 1\% MEM NEAA (Gibco), 1\% L-glutamine (Gibco), 0.1\% $\beta$-Mercaptoethanol (Gibco) and $1 \%$ CHO-LiF. Mouse ES cells were passaged every 2-3 days. For routine passaging, mouse ES cells were

\section{P53+/- mice tumours induced by $75 \mathrm{mg} / \mathrm{kg} \mathrm{MNU}$}
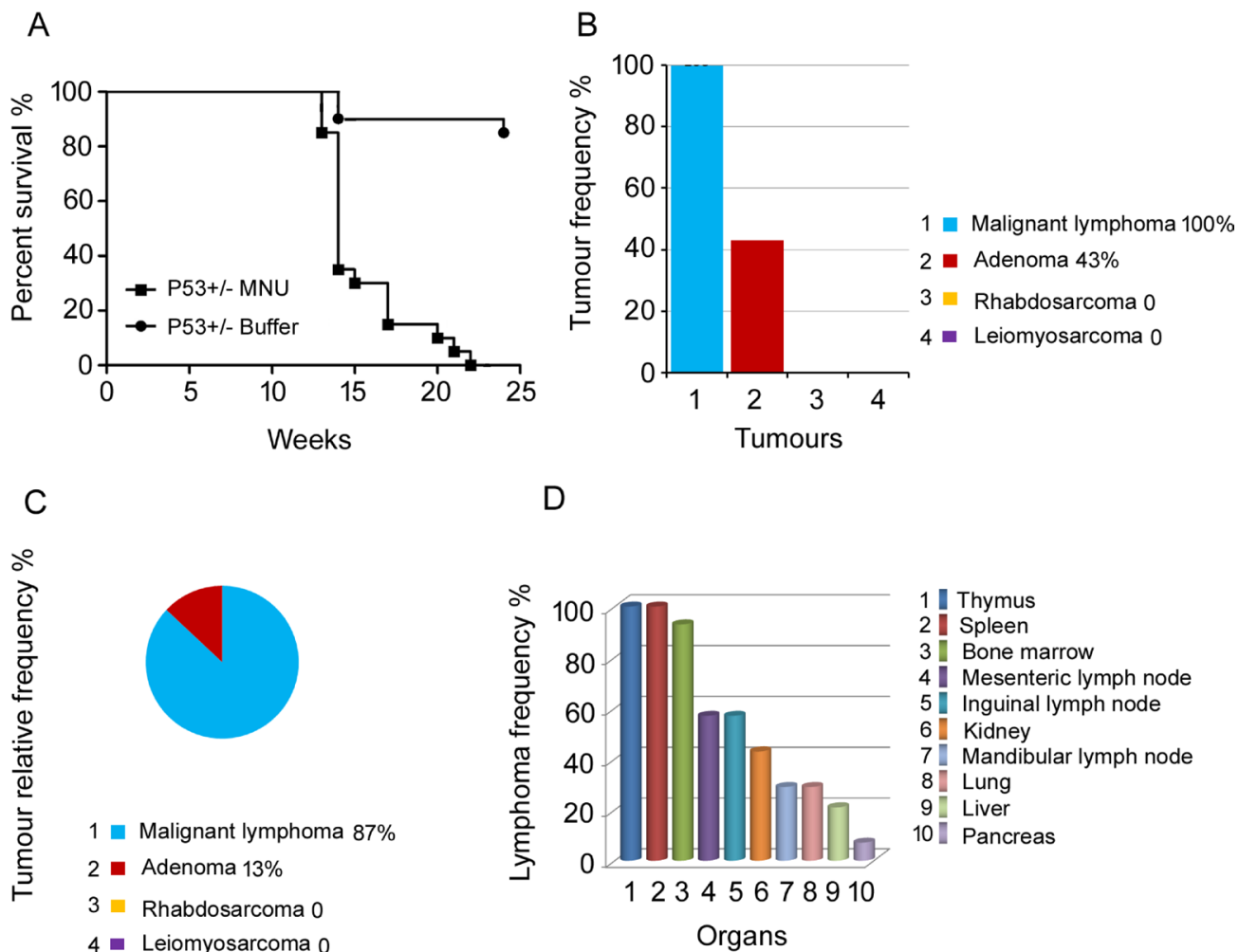

D
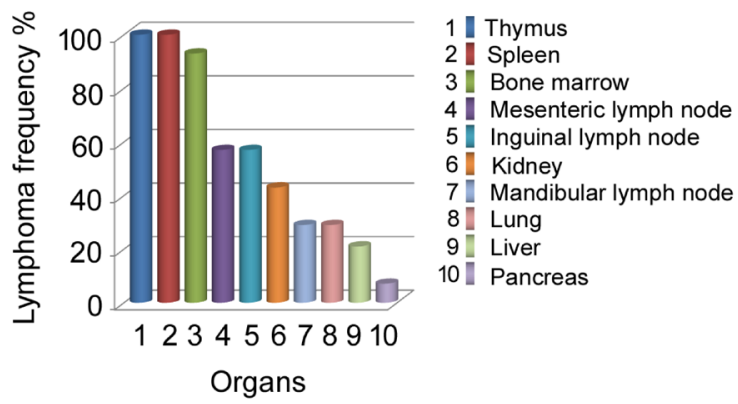

Figure 4: Lymphoma occurrence in p53 deficient heterozygous mice induced by 75 mg/kg MNU. (A) Survival curve of $p 53^{+/}$mice administered $75 \mathrm{mg} / \mathrm{kg}$ MNU. Most animals died between 13-17 weeks after MNU administration. (B) The tumour profile and frequency of $p 53^{+/-}$mice. Lymphoma and adenoma were observed. Notably, the occurrence rate of lymphoma was $100 \%$. (C) Relative tumour frequency of lymphoma, adenoma, rhabdosarcoma, and leiomyosarcoma. (D) The malignant lymphoma frequency in various organs. $14 p 53^{+-}$mice were used in this experiment. 
detached by pipetting and collected by centrifugation. Then, $0.05 \%$ trypsin was added to dissociate the cell aggregates into single cells. Passaging cells in this way avoids a carryover of feeders, which adversely affects mouse ES cell growth.

\section{Karyotype analysis of ES cell lines}

For karyotyping, mouse ES cells were plated onto 6 -well plates at a density of $1 \times 10^{6}$ cells per well. One day after plating, $0.5 \mathrm{mg} / \mathrm{ml}$ colcemid (Sigma) was added to the culture and incubated for $50 \mathrm{~min}$ at $37^{\circ} \mathrm{C}$ water bath. The mouse ES cells were then trypsinised, fixed with methanol-glacial acetic acid (3:1) solution, and spread onto glass-slides. Chromosome G-binding was analysed for karyotypes by microscopy.

\section{Generation of $p 53$ gene knockout mice}

We constructed the mouse $p 53$ gene-targeting vector using a PGK promoter to drive the expression of a neomycin selection cassette (Neo). The targeting vector was introduced into C57BL/6 mouse ES cells by electroporation. After homologous recombination, the targeting vector replaced the p53 gene from exon 2 to 5 . Neomycin resistant ES cell colonies were selected, screened by PCR, and injected into 151 wild-type BALB/c blastocysts. ES-cell-injected blastocysts were then transferred to 14 pseudo-pregnant mice and 8 chimeric mice were produced. The male chimera mice were crossed with wild-type C57BL/6 female mice to generate heterozygous $p 53$ gene knockout mice.

\section{Southern blot analysis}

Genomic DNA was extracted from mouse-tail biopsies and used for Southern blot analysis. After digestion with EcoRI (for the 5' probe), the genomic DNA samples were analysed by gel electrophoresis with a $1 \%$ agarose gel. After electrophoresis, the gel was denatured, neutralized, and blotted by capillary transfer on a nylon membrane. The DNA membrane was fixed and hybridized with digoxigenin-labelled Southern blot hybridization probes according to the manufacturer's instructions (Roche).

\section{Mice genotyping and RNA analysis}

Tail genomic DNA was isolated using a Tissue Genomic DNA Extraction Kit (Generay, Shanghai, China) and then subjected to PCR to verify deletion of

\section{A}

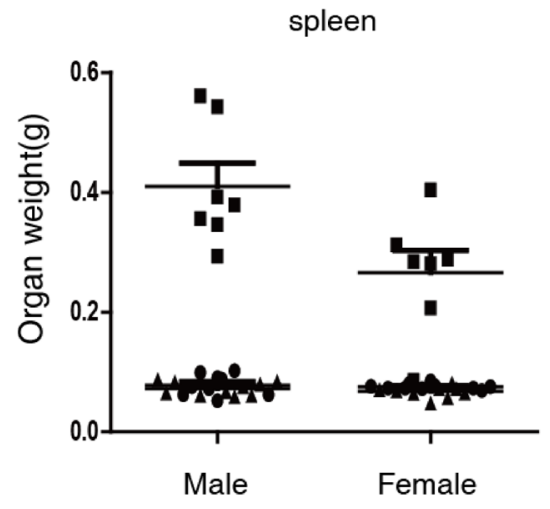

C

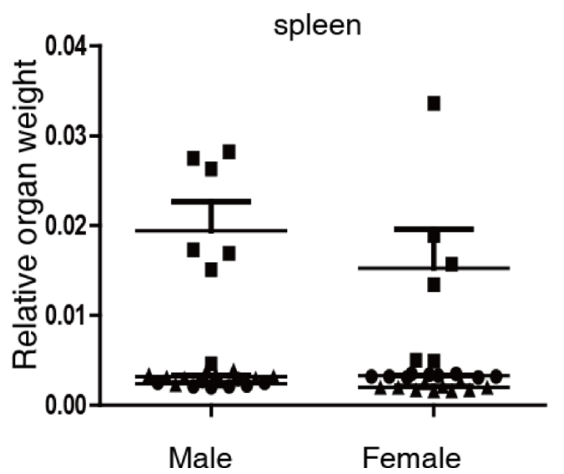

B
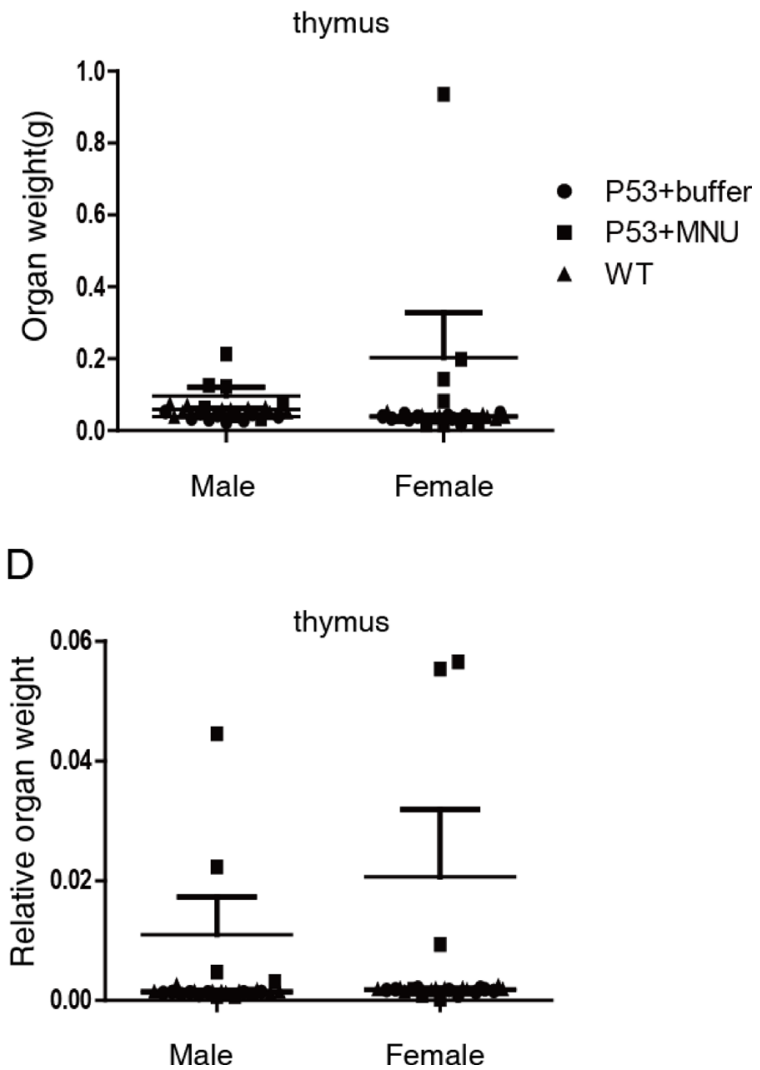

Figure 5: Weight and relative weight of the spleen and thymus of mice treated with or without $75 \mathrm{mg} / \mathrm{kg} \mathrm{MNU}$. (A) Spleen weight of wild-type (WT), and $p 53^{+/-}$mice treated with or without MNU. (B) Thymus weight of WT and $p 53^{+/-}$mice treated with or without MNU. C. Relative weight (organ weight/body weight) of the spleen (C) and thymus (D) of WT and $p 53^{+/-}$mice treated with or without MNU ( $n=7$ per group). 
the p53 gene. Genomic DNA of p53 deficient mice and wild-type mice were amplified with primer sets 1 (P53-WT-F, AGTTCTGCCACGTGGTTGGT; P53WT-R, GTCTCCTGGCTCAGAGGGAG) or 2 (P53WT-F, AGTTCTGCCACGTGGTTGGT; P53-Neo-R, CAGAGGCCACTTGTGTAGCG), with expected PCR products of $281 \mathrm{bp}$ or $441 \mathrm{bp}$ for wild-type and homozygous mutations, respectively. For the heterozygous mutation, both bands were visible.

Tissues were dissected and immediately immersed into RNA later stabilization reagent (Invitrogen) and stored at $-80^{\circ} \mathrm{C}$. Total RNA was extracted from individual tissues using TRIzol (Invitrogen) and quantified using a spectrophotometer at OD $260 \mathrm{~nm}$. Random hexamers were used to prime reverse-transcription reactions with Superscript III (Invitrogen). Real-time quantitative PCR was performed using an ABI 7300 Real Time
PCR System with SYBR green I reagent (Takara Bio Inc.). The primer sets for Q-PCR analysis were $p 53$ F1, 5'-CCCCTGTCATCTT TTGTCCCT-3' and p53 R1, 5'-AGCTGGCAGAATAGCTTATTGAG-3; F2, 5'-CTCTCCCCCGCAAAAGAAAAA $-3^{\prime}$ and R2, 5'-CGGAACATCTCGAAGCGTTTA-3.

\section{Spontaneous malignant lymphoma in $p 53^{-/-}$mice}

Thirty $p 53^{-/-}$mice were maintained for the observation of spontaneous tumours. All mice were observed and palpated daily, and the clinical signs were recorded. Moribund mice were euthanized and anatomized immediately. Dead mice were necropsied immediately or kept at a low temperature and necropsied the next day. Tissues examined for histopathology examination included the adrenal gland, aorta, brain (forebrain, midbrain, and hindbrain), cecum,
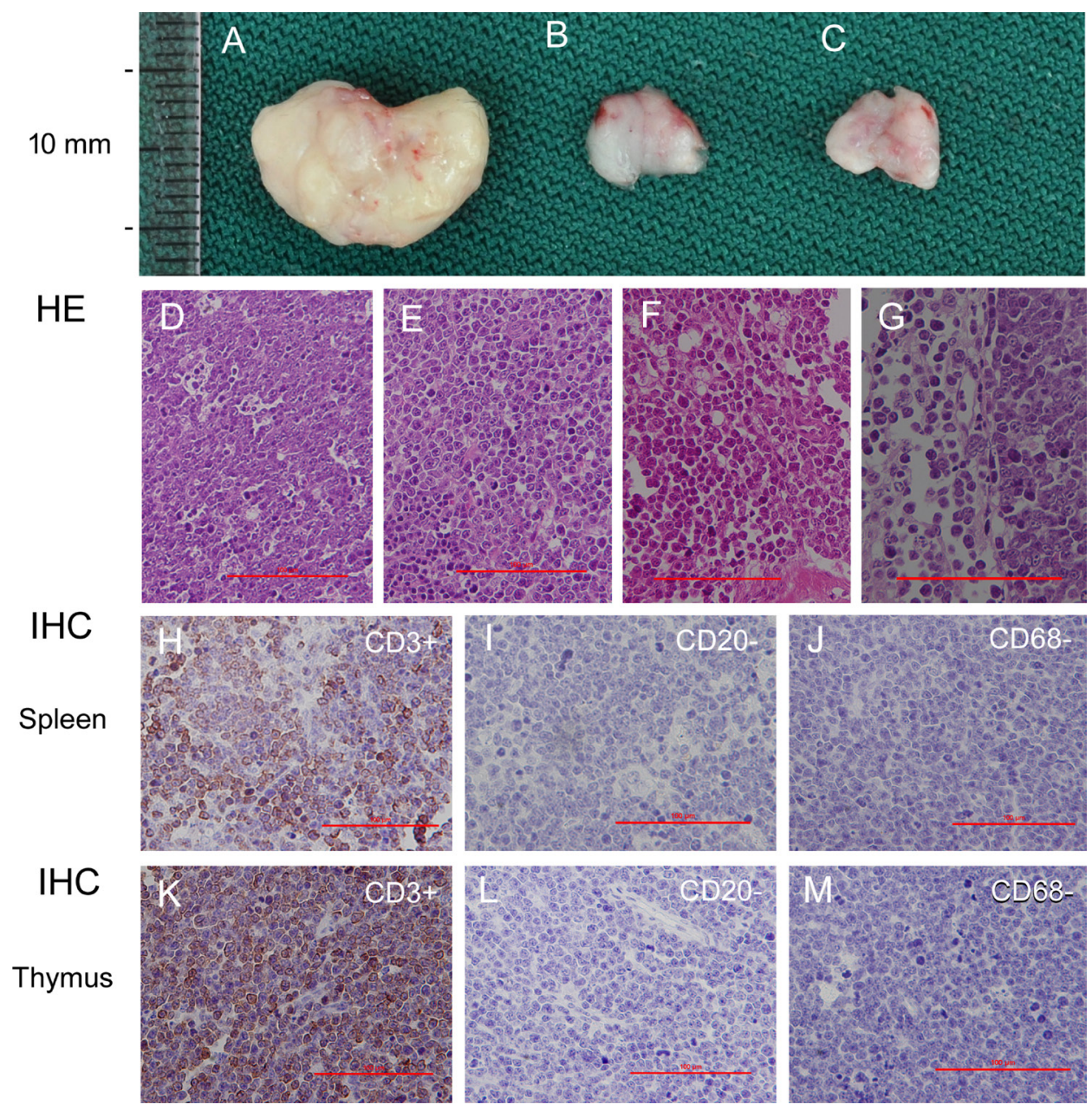

Figure 6: Histopathological features and immunohistochemical analysis of $75 \mathrm{mg} / \mathrm{kg} \mathrm{MNU}$ induced lymphomas in $\mathbf{p 5 3}^{+/-}$gene deficient mice. (A) An enlarged thymus from $p 53^{+/-}$mice administered $75 \mathrm{mg} / \mathrm{kg} \mathrm{MNU}$. (B) Thymus from $p 53^{+/-}$mice receiving citrate buffer. (C) Normal thymus from wild type B6 mice. (D-G) Photomicrographs of the spleen, thymus, bone marrow, and mesenteric lymph node. D-G. Magnification is $\times 100$, bar $=100 \mu \mathrm{m}$. (H-J). Photomicrographs of spleen lymphomas stained using antiCD3, CD20, and CD68 antibodies. H. Spleen lymphomas stained positive for CD3, a T lymphocyte marker. I. The spleen lymphoma stained negative for CD20, a B lymphocyte marker and (J) for CD68, a macrophage marker. (K-M) Photomicrographs of thymus lymphomas stained using anti-CD3, CD20, and CD68 antibodies. K. The thymus lymphoma stained positive for CD3. L. The thymus lymphoma stained negative for CD20, and (M) for CD68. H-M. Magnification is $\times 200$, bar $=100 \mu \mathrm{m}$. 
Table 4: The influence of genetic background on the tumour spectra and lymphoma frequency observed in p53-deficient mice a)

\begin{tabular}{|c|c|c|c|c|c|c|}
\hline Lines & Genetic background of mice & $\begin{array}{l}\text { Induced or } \\
\text { spontaneously }\end{array}$ & $\begin{array}{l}p 53- \\
\text { mutant } \\
\text { alleles }\end{array}$ & $\begin{array}{l}\text { Main tumors spectrum and lymphoma } \\
\text { frequency }\end{array}$ & $\begin{array}{l}\text { Age } \\
\text { (weeks) }\end{array}$ & References \\
\hline L01 & D3 & Spontaneously & $p 53^{+/-}$ & $\begin{array}{l}\text { Osteosarcoma, lymphoma }(25 \%) \text {, } \\
\text { fibrosarcoma; }\end{array}$ & $26-68$ & \multirow{2}{*}{$\begin{array}{l}\text { Jacks et al, } 1994 \\
\text { Jacks et al, } 1994\end{array}$} \\
\hline L02 & D3 & Spontaneously & $p 53^{-/-}$ & $\begin{array}{l}\text { Lymphoma }(71 \%) \text {, rhabdomyosarcoma, } \\
\text { teratoma }\end{array}$ & $26-68$ & \\
\hline L03 & $\mathrm{BABL} / \mathrm{c}^{\mathrm{b})}$ & Spontaneously & $p 53^{+/-}$ & $\begin{array}{l}\text { Mammary carcinoma, lymphoma }(24 \%) \text {, } \\
\text { hemangiosarcoma }\end{array}$ & $>72$ & $\begin{array}{l}\text { Kuperwasser et al, } \\
2000\end{array}$ \\
\hline L04 & $\mathrm{BABL} / \mathrm{c}^{\mathrm{b})}$ & Spontaneously & $p 53^{-/-}$ & $\begin{array}{l}\text { Lymphomas }(53 \%) \text {, hemangiosarcoma, } \\
\text { soft-tissue sarcoma }\end{array}$ & $>72$ & $\begin{array}{l}\text { Kuperwasser et al, } \\
2000\end{array}$ \\
\hline L05 & $129 / \mathrm{Sv}$ & Spontaneously & $p 53^{-/-}$ & $\begin{array}{l}\text { Lymphoma }(65 \%) \text {, testicular, } \\
\text { hemangiosarcoma }\end{array}$ & $5-24$ & Harvey et al, 1993 \\
\hline L06 & $129 / \mathrm{Sv}$ & Spontaneously & $p 53^{+/-}$ & Osteosarcoma, lymphoma (22\%) & $>100$ & $\begin{array}{l}\text { Donehower LA, } \\
1995\end{array}$ \\
\hline L07 & $129 / \mathrm{Sv}$ & Spontaneously & $p 53^{-/-}$ & Lymphomas (47\%), malignant teratoma & $>100$ & $\begin{array}{l}\text { Donehower LA, } \\
1995\end{array}$ \\
\hline L08 & $75 \% \mathrm{C} 57 \mathrm{BL} / 6,25 \% 129 / \mathrm{Sv}$ & Spontaneously & $p 53^{-/-}$ & $\begin{array}{l}\text { Lymphoma ( } 69 \%) \text {, hemangiosarcoma, } \\
\text { sacrcoma }\end{array}$ & $8-37$ & $\begin{array}{l}\text { Donehower et al, } \\
1992\end{array}$ \\
\hline L09 & $75 \%$ C57BL/6, 25\% 129/Sv & Spontaneously & $p 53^{-/-}$ & $\begin{array}{l}\text { Lymphoma }(75 \%) \text {, hemangiosarcoma, } \\
\text { testicular tumors }\end{array}$ & ndf) & Harvey et al, 1993 \\
\hline L10 & $75 \%$ C $57 \mathrm{BL} / 6,25 \% 129 / \mathrm{Sv}$ & Spontaneously & $p 53^{+/-}$ & Osteosarcoma, lymphoma (28\%) & $>100$ & $\begin{array}{l}\text { Donehower LA, } \\
1995\end{array}$ \\
\hline L11 & $75 \% \mathrm{C} 57 \mathrm{BL} / 6,25 \% 129 / \mathrm{Sv}$ & Spontaneously & $p 53^{-/-}$ & Lymphoma (65\%), hemangiosarcoma & $>100$ & $\begin{array}{l}\text { Donehower LA, } \\
1995\end{array}$ \\
\hline L12 & B6.129-Trp53 N5c) & Induced $^{\mathrm{d})}$ & $p 53^{+/-}$ & $\begin{array}{l}\text { Lymphoma }(85 \%) \text {, adenoma, } \\
\text { adenocarcinoma }\end{array}$ & 26 & Morton et al, 2008 \\
\hline L13 & $100 \% \mathrm{C} 57 \mathrm{BL} / 6$ & Spontaneously & $p 53^{-/-}$ & $\begin{array}{l}\text { Lymphoma }(90.5 \%) \text {, eiomyoma, } \\
\text { rhabdosarcoma }\end{array}$ & $12-32$ & This work \\
\hline L14 & $100 \% \mathrm{C} 57 \mathrm{BL} / 6$ & Induced $^{\mathrm{d})}$ & $P 53^{+/-}$ & Lymphoma (100\%), adenoma & $24-26$ & This work \\
\hline L15 & $100 \% \mathrm{C} 57 \mathrm{BL} / 6$ & Induced ${ }^{\mathrm{e}}$ & $P 53^{+/+}$ & Lymphoma (10\%) & $24-26$ & This work \\
\hline L16 & $100 \% \mathrm{C} 57 \mathrm{BL} / 6$ & Induced $^{\mathrm{e}}$ & $P 53^{+/-}$ & Lymphoma $(65 \%)$ & $24-26$ & This work \\
\hline
\end{tabular}

a) Only the top three kinds of the tumour were showed and the lymphoma frequencies were indicated.

b) $\mathrm{C} 57 \mathrm{BL} / 6 \times 129 / \mathrm{Sv}$ p53-deficient mice was backcrossed for nine generations onto the BALB/c strain;

c) $129 / \mathrm{Sv}$ p53-deficient mice was backcrossed for five generations onto the C57BL/6 strain, about $97 \%$ of C57BL/6 background;

d) Induced by $75 \mathrm{mg} / \mathrm{kg} \mathrm{MNU}$;

e) Induced by $37.5 \mathrm{mg} / \mathrm{kg} \mathrm{MNU}$;

f) nd: not determined.

colon, duodenum, epididymis, oesophagus, eyes, femur with bone marrow, Harderian glands, heart, ileum, jejunum, gall bladder, kidneys, liver, lung with bronchi, lymph nodes (mesenteric and mandibular), mammary gland (female only), optic nerves, ovaries, oviduct, pancreas, pituitary prostate, rectum, salivary gland, sciatic nerve, seminal vesicles, skeletal muscle(thigh), skin and subcutis, spinal cord (cervical, thoracic, and lumbar), spleen, sternum with bone marrow, stomach, testis, thymus, thyroid and parathyroid glands, tongue, trachea, tumours/masses, urinary bladder, uterus with cervix, vagina, and gross lesions.

\section{MNU induced malignant lymphoma in $p 53^{+/-}$ mice}

Thirty C57BL/6 wild-type mice and fifty $p 53^{+/-}$ deficient mice (almost half male and half female) were grouped and administered 37.5 or $75 \mathrm{mg} / \mathrm{kg}$ MNU or citrate buffer as a control. MNU was dissolved in citrate buffered saline and adjusted to $\mathrm{pH} 4.5$ before a single dose administration to animals by intraperitoneal injection on Day 1 followed by a six-month observation period. All mice were observed twice daily, and clinical signs were recorded once daily. Body weights were recorded at least once before treatment and weekly following treatment. Beginning 12 weeks after treatment, mice were palpated weekly until the end of the study. All surviving animals were sacrificed and necropsied at the end of 26 weeks.

\section{Immunohistochemical analysis and flow cytometry}

Mouse tissues were fixed in $10 \%$ neutral buffered formalin, embedded in paraffin, and sectioned $(5 \mu \mathrm{m})$. 
For histopathological examination, tissue sections were stained with haematoxylin and eosin.

Immunohistochemical stains were applied to formalin-fixed, paraffin-embedded sections of the thymus from five animals per gender with thymic malignant lymphoma in the MNU-treated group and to thymic sections from two control males and two control females. Antibodies directed against CD3 (T-lymphocyte marker), CD20 (B-lymphocyte marker), and CD68 (macrophage marker) were used to classify the lineage of the neoplastic cells in the thymus. Thymic malignant lymphoma or thymic sections for CD3, CD20, and CD68 staining were pretreated by incubating at $96^{\circ} \mathrm{C}$ in Citra buffer (Zhongshan Golden Bridge Biocompany, Beijing, China) at $\mathrm{pH} 6$ in a microwave oven for 10 minutes. Sections for CD3 staining were incubated with anti-CD3 antibody (clone LN10, Zhongshan Golden Bridge Biocompany, Beijing, China) at a $1: 150$ dilution overnight at $4^{\circ} \mathrm{C}$ after blocking with normal goat serum for 60 minutes at $37^{\circ} \mathrm{C}$. The sections for $\mathrm{CD} 20$ staining were incubated with anti-CD20 antibody (clone EP7, Zhongshan Golden Bridge Biocompany, Beijing, China) at a dilution of 1:200 overnight at $4^{\circ} \mathrm{C}$ after blocking with normal goat serum for 60 minutes at $37^{\circ} \mathrm{C}$. The sections for CD68 staining
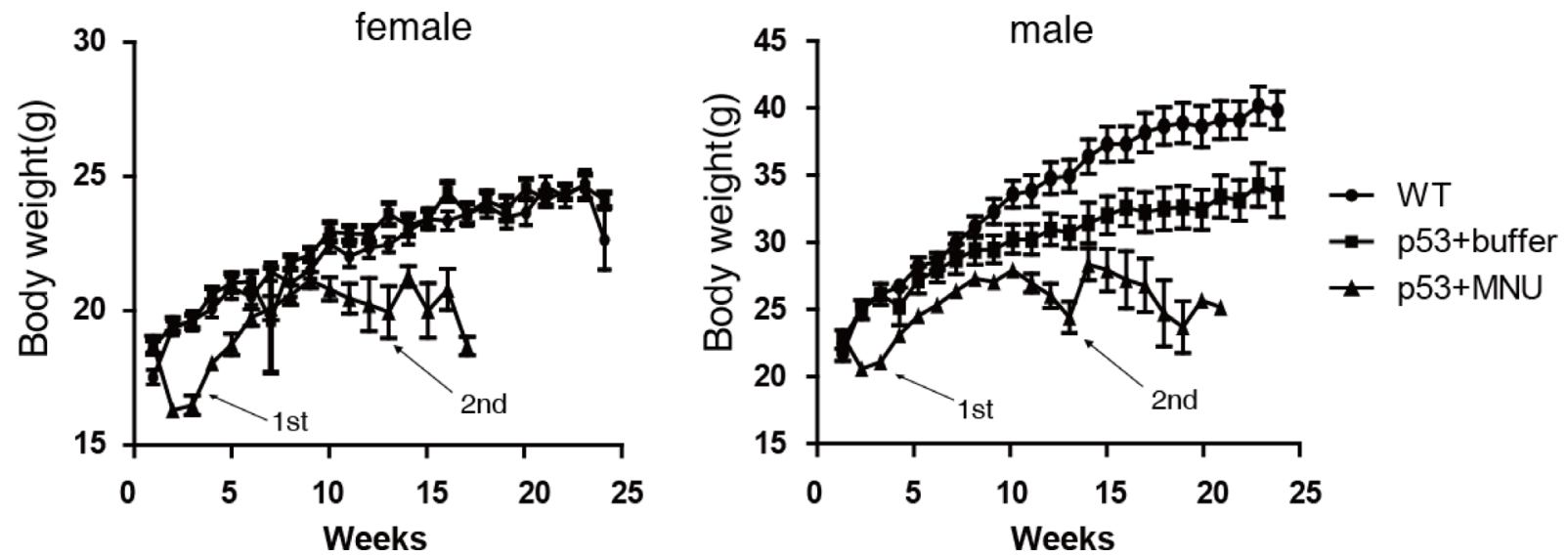

Figure 7: Dynamics of body weight in male and female mice treated with or without 75 mg/kg MNU. Troughs of body weight of mice treated with MNU were observed at 2-3 weeks and 12-13 weeks as indicated by arrows. The second trough is consistent with the moribund or death of animals. Data are presented as the mean \pm standard deviation ( $n=10$ per group).

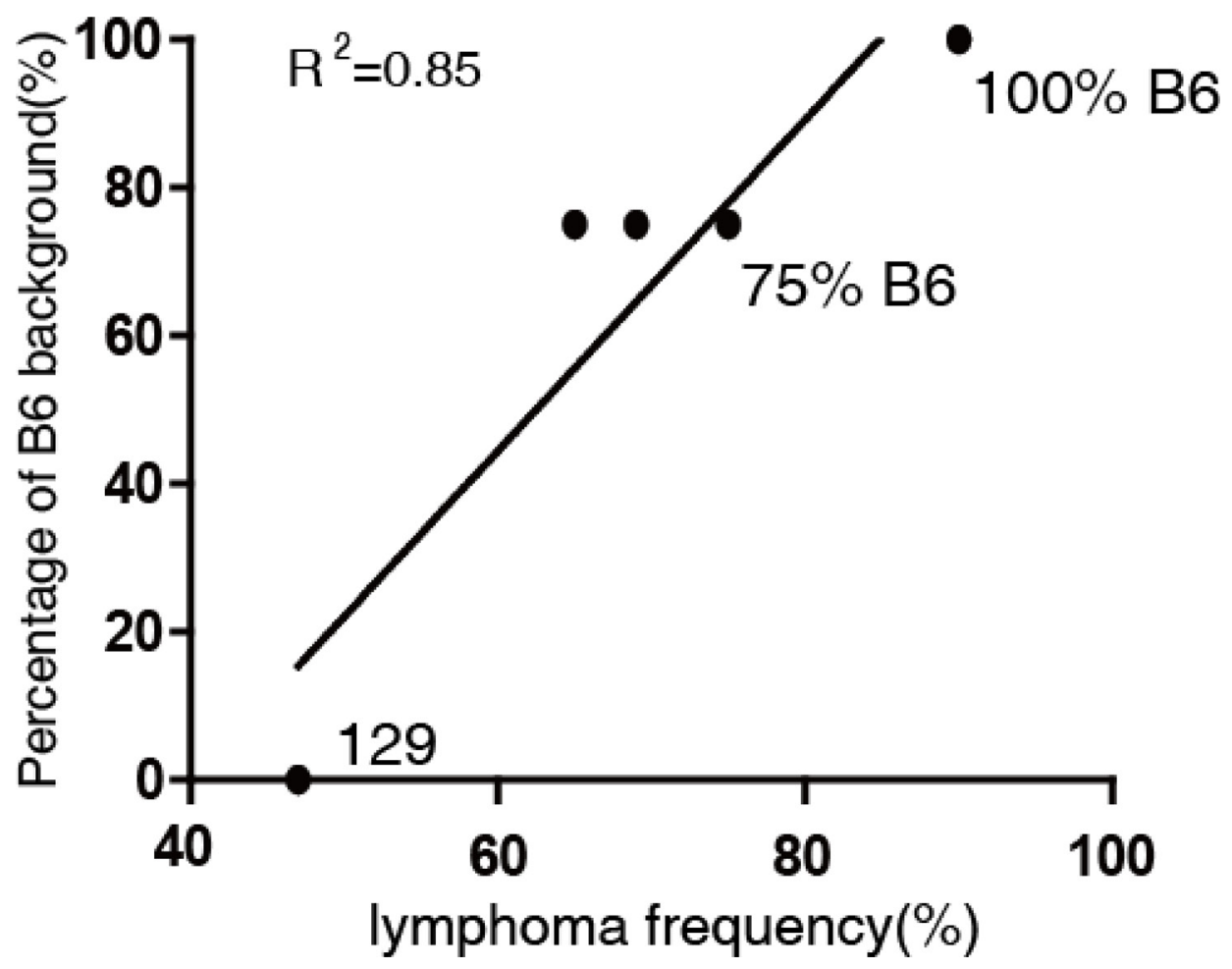

Figure 8: Relationship between rate of lymphoma occurrence and genetic background. Genetic background is labelled in the panel. $\mathrm{R}^{2}$ represents the coefficient of determination, original data and references listed in Table 4. 
were incubated with anti-CD68 antibody (clone PG-M1, Zhongshan Golden Bridge Biocompany, Beijing, China) at a dilution of 1:200 overnight at $4^{\circ} \mathrm{C}$ after blocking with normal goat serum for 60 minutes at $37^{\circ} \mathrm{C} . \mathrm{CD} 3$, CD20, and CD68 immunoreactivity were all detected using a biotinylated rabbit anti-rat secondary antibody followed by an avidin-biotin-horseradish peroxidase complex and visualized with diaminobenzidine. All immunohistochemical sections were counterstained with haematoxylin, dehydrated in graded concentrations of ethanol, and coverslipped routinely using permanent mounting medium.

To detect CD4, CD8 positive cells, enlarged thymus and spleen of $p 53^{-/-}$mice over six months (according to previous experiments, usually indicating lymphoma has occurred) were collected and using BD FACS Calibur (Becton Dickinson, Franklin Lakes, NJ, USA) to perform multicolour cytometric analysis. The erythrocytes in the thymus and spleen cells were depleted by Lysing solution (BD Phar Mingen, San Diego, CA, USA). Anti-mouse CD4 and CD8 monoclonal antibodies were purchased from BD Phar Mingen.

\section{Statistical analysis}

The Fisher exact test was used to analyse tumour incidence data and the Fisher least significant difference test was used to analyse body and organ weights. The statistical analysis result of haematology data was shown as the mean \pm standard deviation (SD) or One-Way Analysis of Variance (ANOVA). SPSS 19.0 software was used to analyse the results. Dunnett's parametric test was used for multiple comparisons between groups. $P<$ 0.05 was considered statistically significant. $P<0.01$ was considered highly significant.

\section{Abbreviations}

MNU: N-methyl-N-nitrosourea. SD: standard deviation. WBC: white blood cell. NEU: neutrophil count. LYM: lymphocyte count. MONO: Monocytes count. EOS: Eosinophil count. BASO: basophile count. RBC: Red blood cell. RDW: red blood cell distribution width. HDW: haemoglobin distribution width. HCT: haematocrit. $\mathrm{MCV}$ : mean corpuscular volume. $\mathrm{MCH}$ : mean corpuscular haemoglobin. HGB: haemoglobin. MCHC: Red blood cell haemoglobin concentration. PLT: platelet count. ALT: Alanine aminotransferase. AST: Aspartate aminotransferase. TP: total protein. ALB: albumen. GLU: glucose. CREA: creatinine. UREA: urea nitrogen. TCHO: cholesterol. TG: triglyceride. CA: Calcium.

\section{Author contributions}

Youchun Wang, Changfa Fan, Jianjun Lyu, Xue Wang designed research. Susu Liu, Qianqian Li, Yanwei
Yang, Guitao Huo, Qin Zuo, Qingfen Zhu, Ming Guo performed research. Xi Wu, Shuya Zhou, Simei Ren, Yanan Guo, Sanlong Wang, Baowen Li, Yuelei Shen analysed data. Changfa Fan, Jianjun Lyu, Xi Wu wrote the paper.

\section{ACKNOWLEDGMENTS}

We thank Chenfei Wang and Dr. Meng Wang for technical support in this study.

\section{CONFLICTS OF INTEREST}

The authors declare no conflicts of interest.

\section{FUNDING}

This work is supported by National Natural Science Foundation of China (Grant number: 81502396 to Xi Wu) and National Science and Technology Support Project (Grant number: 2014BAI02B01 to Yuelei Shen).

\section{REFERENCES}

1. Erker C, Harker-Murray P, Burke MJ. Emerging immunotherapy in pediatric lymphoma. Future Oncol. 2016; 12:257-70. https://doi.org/10.2217/fon.15.282.

2. Calman KC. Why are small bowel tumours rare? An experimental model. Gut. 1974; 15:552-4.

3. Nakamura D, Yoshimitsu M, Kuroki A, Hachiman M, Kamada Y, Ezinne CC, Arai A, Inoue H, Hamada H, Hayashida M, Suzuki S, Fujino S, Arima N, et al. A new ATL xenograft model and evaluation of pyrrolidine dithiocarbamate as a potential ATL therapeutic agent. Exp Hematol. 2015; 43:944-50. https://doi.org/10.1016/j. exphem.2015.06.303.

4. Zhang X, Deng Y, Chen FL, Fang YJ, Zhang W, Yu L. [Establishment of Human Acute B-Lymphoblastic Leukemia--NOD/SCID Xenotransplant Mouse Model]. Zhongguo Shi Yan Xue Ye Xue Za Zhi. 2015; 23:623-6. https://doi.org/10.7534/j.issn.1009-2137.2015.03.004.

5. Sun-Hoffman L, Winicov I. MNU affects mouse erythroleukemia cell differentiation at sub-cytotoxic doses. Chem Biol Interact. 1996; 100:241-54.

6. Donehower LA, Harvey M, Vogel H, McArthur MJ, Montgomery CA Jr, Park SH, Thompson T, Ford RJ, Bradley A. Effects of genetic background on tumorigenesis in p53-deficient mice. Mol Carcinog. 1995; 14:16-22.

7. Kuperwasser C, Hurlbut GD, Kittrell FS, Dickinson ES, Laucirica R, Medina D, Naber SP, Jerry DJ. Development of spontaneous mammary tumors in BALB/c p53 heterozygous mice. A model for Li-Fraumeni syndrome. Am J Pathol. 2000; 157:2151-9. https://doi.org/10.1016/ S0002-9440(10)64853-5. 
8. Morton D, Bailey KL, Stout CL, Weaver RJ, White KA, Lorenzen MJ, Ball DJ. N-Methyl-N-Nitrosourea (MNU): A positive control chemical for $\mathrm{p} 53+/-$ mouse carcinogenicity studies. Toxicol Pathol. 2008; 36:926-31. https://doi. org/10.1177/0192623308324959.

9. Kelliher MA, Seldin DC, Leder P. Tal-1 induces T cell acute lymphoblastic leukemia accelerated by casein kinase IIalpha. EMBO J. 1996; 15:5160-6.

10. Chervinsky DS, Lam DH, Zhao XF, Melman MP, Aplan PD. Development and characterization of $\mathrm{T}$ cell leukemia cell lines established from SCL/LMO1 double transgenic mice. Leukemia. 2001; 15:141-7.

11. Donehower LA, Harvey M, Slagle BL, McArthur MJ, Montgomery CA Jr, Butel JS, Bradley A. Mice deficient for p53 are developmentally normal but susceptible to spontaneous tumours. Nature. 1992; 356:215-21. https:// doi.org/10.1038/356215a0.

12. Harvey M, McArthur MJ, Montgomery CA Jr, Bradley A, Donehower LA. Genetic background alters the spectrum of tumors that develop in p53-deficient mice. FASEB J. 1993; 7:938-43.

13. Knudson AG Jr. Mutation and cancer: statistical study of retinoblastoma. Proc Natl Acad Sci USA. 1971; 68:820-23.

14. Jacks T, Remington L, Williams BO, Schmitt EM, Halachmi $\mathrm{S}$, Bronson RT, Weinberg RA. Tumor spectrum analysis in p53-mutant mice. Curr Biol. 1994; 4:1-7.

15. Hanahan D, Weinberg RA. Hallmarks of cancer: the next generation. Cell. 2011; 144:646-74. https://doi. org/10.1016/j.cell.2011.02.013.

16. Takaoka M, Sehata S, Maejima T, Imai T, Torii M, Satoh H, Toyosawa K, Tanakamaru ZY, Adachi T, Hisada S, Ueda M, Ogasawara $\mathrm{H}$, Matsumoto $\mathrm{M}$, et al. Interlaboratory comparison of short-term carcinogenicity studies using CB6F1-rasH2 transgenic mice. Toxicol Pathol. 2003; 31:191-9.

17. Wang X, Werneck MB, Wilson BG, Kim HJ, Kluk MJ, Thom CS, Wischhusen JW, Evans JA, Jesneck JL, Nguyen P, Sansam CG, Cantor H, Roberts CW. TCR-dependent transformation of mature memory phenotype $\mathrm{T}$ cells in mice. J Clin Invest. 2011; 121:3834-45. https://doi. org/10.1172/JCI37210.

18. Kenzelmann Broz D, Attardi LD. In vivo analysis of $\mathrm{p} 53$ tumor suppressor function using genetically engineered mouse models. Carcinogenesis. 2010; 31:1311-8. https:// doi.org/10.1093/carcin/bgp331.

19. Keskintepe L, Norris K, Pacholczyk G, Dederscheck SM, Eroglu A. Derivation and comparison of C57BL/6 embryonic stem cells to a widely used 129 embryonic stem cell line. Transgenic Res. 2007; 16:751-8. https://doi. org/10.1007/s11248-007-9125-8.

20. Cong L, Ran FA, Cox D, Lin S, Barretto R, Habib N, Hsu PD, Wu X, Jiang W, Marraffini LA, Zhang F. Multiplex genome engineering using CRISPR/Cas systems. Science. 2013; 339:819-23. https://doi.org/10.1126/ science. 1231143
21. Danforth DN Jr. Genomic Changes in Normal Breast Tissue in Women at Normal Risk or at High Risk for Breast Cancer. Breast Cancer (Auckl). 2016; 10:109-46. https:// doi.org/10.4137/BCBCR.S39384.

22. Narayan S, Jaiswal AS, Law BK, Kamal MA, Sharma AK, Hromas RA. Interaction between APC and Fen1 during breast carcinogenesis. DNA Repair (Amst). 2016; 41:5462. https://doi.org/10.1016/j.dnarep.2016.04.003.

23. Sonnenschein C, Soto AM. Carcinogenesis explained within the context of a theory of organisms. Prog Biophys Mol Biol. 2016; 122:70-76. https://doi.org/10.1016/j. pbiomolbio.2016.07.004

24. Vousden $\mathrm{KH}, \mathrm{Lu} \mathrm{X}$. Live or let die: the cell's response to p53. Nat Rev Cancer. 2002; 2:594-604. https://doi. org/10.1038/nrc864.

25. Vousden KH, Prives C. Blinded by the Light: The Growing Complexity of p53. Cell. 2009; 137:413-31. https://doi. org/10.1016/j.cell.2009.04.037.

26. Soussi T. p53 alterations in human cancer: more questions than answers. Oncogene. 2007; 26:2145-56. https://doi. org/10.1038/sj.onc.1210280.

27. Ooms AH, Gadd S, Gerhard DS, Smith MA, Guidry Auvil JM, Meerzaman D, Chen QR, Hsu CH, Yan C, Nguyen C, Hu Y, Ma Y, Zong Z, et al. Significance of TP53 Mutation in Wilms Tumors with Diffuse Anaplasia: A Report from the Children's Oncology Group. Clin Cancer Res. 2016; 22:558291. https://doi.org/10.1158/1078-0432.CCR-16-0985.

28. Fahrer J, Kaina B. Impact of DNA repair on the doseresponse of colorectal cancer formation induced by dietary carcinogens. Food Chem Toxicol. 2017; 106:583-594.

29. Lee BS, Park SJ, Kim YB, Han JS, Jeong EJ, Son HY, Moon KS. Twenty-six-week oral carcinogenicity study of 3-monochloropropane-1,2-diol in CB6F1-rasH2 transgenic mice. Arch Toxicol. 2017; 91:453-464. https://doi.org/10.1007/s00204016-1696-9.

30. Sunaoshi M, Amasaki Y, Hirano-Sakairi S, Blyth BJ, Morioka T, Kaminishi M, Shang Y, Nishimura M, Shimada Y, Tachibana A, Kakinuma S. The effect of age at exposure on the inactivating mechanisms and relative contributions of key tumor suppressor genes in radiation-induced mouse T-cell lymphomas. Mutat Res. 2015; 779:58-67. https://doi. org/10.1016/j.mrfmmm.2015.06.004.

31. Laur AM, Floch P, Chambonnier L, Benejat L, Korolik V, Giese A, Dubus P, Megraud F, Bandeira A, Lehours P. Regulatory $\mathrm{T}$ cells may participate in Helicobacter pylori persistence in gastric MALT lymphoma: lessons from an animal model. Oncotarget. 2016; 7:3394-402. https://doi. org/10.18632/oncotarget.6492.

32. Smith GS, Walford RL, Mickey MR. Lifespan and incidence of cancer and other diseases in selected long-lived inbred mice and their F 1 hybrids. J Natl Cancer Inst. 1973; 50:1195-213.

33. Li Z, Xia Y, Feng LN, Chen JR, Li HM, Cui J, Cai QQ, Sim KS, Nairismägi ML, Laurensia Y, Meah WY, Liu WS, Guo 
YM, et al. Genetic risk of extranodal natural killer T-cell lymphoma: a genome-wide association study. Lancet Oncol. 2016; 17:1240-47.

34. Beljaards RC, Meijer CJ, Van der Putte SC, Hollema H, Geerts ML, Bezemer PD, Willemze R. Primary cutaneous
T-cell lymphoma: clinicopathological features and prognostic parameters of 35 cases other than mycosis fungoides and CD30-positive large cell lymphoma. J Pathol. 1994; 172:53-60. https://doi.org/10.1002/path.1711720110. 